\title{
NOTES
}

\section{SUSTAINABILITY OF THE LEGAL PROFESSION AMID THE COVID-19 PANDEMIC SITUATION}

\author{
Damar Sinatria Saputro \\ Faculty of Law, Universitas Negeri Semarang, Indonesia \\ Email: damardo@student.mail.unnes.ac.id
}

\begin{abstract}
The rapid spread of the corona virus certainly affects the disruption of the daily activities of the community both in the area that has been turned into a red zone or even not yet. The provisions for determining national disasters have been stipulated in Law No. 24 of 2007 concerning Disaster Management. In fact, the determination of the status and level of disasters has also been regulated by Presidential Regulation No. 17 of 2018 concerning the Implementation of Disaster Management in Certain Conditions. The virus that sufferers experience symptoms such as fever, dry cough, and difficulty breathing is of course disrupting many sectors, the legal sector certainly is not spared and of course experienced interference. Activities in the field of law are one of the areas that rely heavily on human relations in close proximity. Almost all activities in the field of law require us to be close to other humans. With the corona virus that requires us to keep our distance with others, of course this is very difficult if we want to carry out activities in the field of law that is usually done. Not to mention the fact that the government encourages us to stay at home, then also the closure of various roads that make our Movement very limited.
\end{abstract}

Keywords: Legal Profession; Covid-19; Sustainability

The Indonesian Journal of International Clinical Legal Education ISSN 2721-8368

DOI: $10.15294 /$ ijicle.v2i2.38333

(C) 2020 Authors. This work is licensed under a Creative Commons Attribution-ShareAlike 4.o International License. All writings

published in this journal are personal views of the authors and do not represent the views of this journal and the author's affiliated institutions.

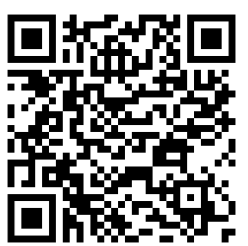


THE RAPID SPREAD OF THE CORONA VIRUS CERTAINLY affects the disruption of the daily activities of the community both in the area that has been turned into a red zone or even not yet. The provisions for determining national disasters have been stipulated in Law No. 24 of 2007 concerning Disaster Management. In fact, the determination of the status and level of disasters has also been regulated by Presidential Regulation No. 17 of 2018 concerning the Implementation of Disaster Management in Certain Conditions. The virus that sufferers experience symptoms such as fever, dry cough, and difficulty breathing is of course disrupting many sectors, the legal sector certainly is not spared and of course experienced interference.

Activities in the field of law are one of the areas that rely heavily on human relations in close proximity. Almost all activities in the field of law require us to be close to other humans. With the corona virus that requires us to keep our distance with others, of course this is very difficult if we want to carry out activities in the field of law that is usually done. Not to mention the fact that the government encourages us to stay at home, then also the closure of various roads that make our Movement very limited.

Even the police and military plan to arrest people who are still determined to gather in public places. The police and the TNI are currently actively conducting raids on various entertainment venues or hangouts which are feared to be a place for the spread of the corona virus in Indonesia.

Judges and officials who experience illnesses, especially coughs, colds, fevers, and shortness of breath, and / or have a history of interactions with parties or the environment that is confirmed to have contracted COVID-19, may be given permission to not enter the office by the respective work unit leaders pay attention to the situation and environmental conditions of the office and the local area. Criminal proceedings, military criminal proceedings, and jinayat continue to take place in accordance with the established trial schedule.

Whereas in civil, religious and state administration trials, justice seekers are encouraged to take advantage of e-litigation. Related to the work system in the Supreme Court of Justice, the Supreme Court has issued a Circular Letter (SEMA) No. 1 of 2020 concerning Guidelines for Implementing Tasks During the Prevention Period of Covid-19 Spread in the Supreme Court and its Judicial Bodies.

The Driving License service is also stopped until the situation is declared safe or normal. The party concerned itself has taken the Actions if there is a SIM that has expired will get relief by simply extending it, not making it new.

Unlike the SIM Services that are temporarily closed, the prosecutors take a different lahah that is by continuing to hold a trial but 
through online. This has proven to be effective because it does not require direct contact.

Responding to the development of the spread of Corona Virus 2019 (Covid-19) which is increasingly widespread in Indonesia, finally the Supreme Court (MA) tightened the work system in the judiciary, especially in the courts for criminal cases that are still running. MA published SEMA No. 1 of 2020 concerning Guidelines for Implementing Tasks During the Prevention Period of Covid-19 Spread in the Supreme Court and its Judicial Bodies. In this circular there are conditions for holding an online trial.

The KPK itself reminds all parties not to take advantage of opportunities in the current non-natural disaster situation related to the corona virus outbreak. Article 2 paragraph (2) of Law No. 20 of 2001 concerning Amendments to Law No. 31 of 1999 concerning Eradication of Corruption regulates the threat of punishment and criminal prosecution for perpetrators of criminal acts of corruption against funds intended for the purpose of overcoming danger situations, national natural disasters and so forth with the threat of a maximum sentence of death.

As for the legal aid service myself, at this time I haven't found any concrete data, but based on the information that I got, some legal aid agencies currently work by working from home or working from home. Although it is indeed not optimal, this method can certainly be an alternative if the case being handled is indeed very urgent.

With the examples above, it can be concluded that in the field of law, the effects caused by the presence of this virus are very troublesome and unfortunately there is no definitive solution that can solve the problems caused.

The solution to move using online-based media can certainly be an option, but with the current situation of the Indonesian people I can say that using online-based media is not effective, there are still many people who are blind to the internet, let alone have internet access. Not to mention about the media itself, whether using the application itself or using a third party application? Then if you use a third-party application the data can be safe? Of course this needs to be thought out carefully.

To think of the right solution, in my opinion, will require a lot of time, especially for its application which certainly requires a lot of time. Of course this can be taken into consideration if the parties concerned plan to continue carrying out the activities involved.

For this reason, my suggestion is that activities in the field of law must be terminated first. And in this free time, the parties concerned can begin to think of ways so that after this pandemic ends we can fix cases that might be stopped or even damaged by this long time.

With the existence of a legal umbrella that regulates the dismissal of cases or problems in the field of law in my opinion will make the 


\section{Saputro}

people concerned a little calmer. With this they can focus more on activities that I think are more important, namely Health.

But keep in mind, the related parties as the responsible party must be able to provide the best solution so that when the situation is conducive, the activities in the legal field can take place without any obstacles. Do not let this incident even make certain parties harmed. Because it really needs to be recognized with this incident can create a gap that certainly can be used by parties who are not responsible.

For this reason, my friends and I as law students should also oversee the regulations issued by the government both in the field of law and other fields. Do not let a country that is injured enough due to this pandemic more injured because of irresponsible parties. 